I N T ER N ATIONAL MONETARY FUND

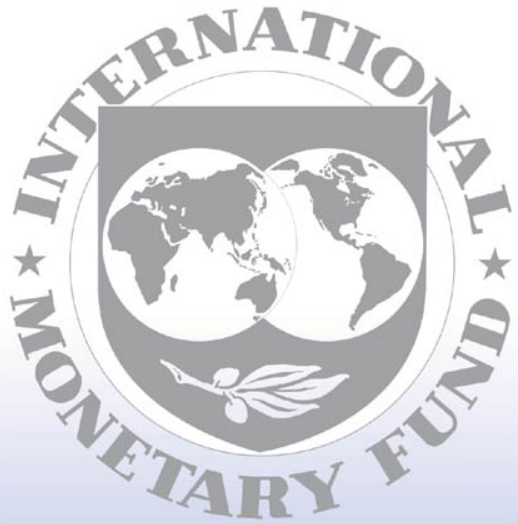

Staff

Country

Reports 


\section{Finland: Staff Report for the 2000 Article IV Consultation}

As required under Article IV of its Articles of Agreement, the International Monetary Fund conducts periodic consultations with its member countries. In the context of the 2000 Article IV consultation with Finland, the following documents have been released and are included in this package:

- the staff report for the 2000 Article IV consultation, prepared by a staff team of the IMF, following discussions that ended on June 12, 2000, with the officials of Finland on cconomic developments and policies. Based on information available at the time of these discussions, the staff report was completed on July 31, 2000. The views expressed in the staff report are those of the staff team and do not necessarily reflect the views of the Executive Board of the IMF;

- the Public Information Notice (PIN), which summarizes the views of the Executive Board in concluding the Article IV consultation on August 22, 2000.

Further background documentation prepared by IMF staff for the consultation may be published separately at a later date. The policy of publication of Article IV staff reports and PINS allows for the deletion of market-sensitive information.

The Article IV staff report is published-both in hard copy and on the IMF's website (http://www.imf.org)-as part of a pilot project. To assist the IMF in evaluating the pilot project for release of Article IV staff reports, reader cornments are invited prior to October 5, 2000, and may be sent by e-mail to Pilotproject(imfim.org.

Copies of this report are available to the public from

International Monetary Fund - Publication Services

70019 th Street, N.W. - Washington, D.C. 20431

Telephone: (202) 6237430 - Telefax: (202) 6237201

E-mail: publications@imf.org •Internet: http://mww.imf org

Price: $\$ 15.00$ a copy

\section{International Monetary Fund}

Washington, D.C. 
INTERNATIONAL MONETARY FUND

FINLAND

\section{Staff Report for the 2000 Article IV Consultation}

Prepared by the Staff Representatives for the 2000 Consultation with Finland

Approved by Michael Deppler and G. Russell Kincaid

July 31,2000

- A staff team held Article IV consultation discussions in Helsinki during June 5-12, 2000, with the Minister of Finance, the Governor of the Bank of Finland, and officials from the Bank of Finland and the Ministries of Finance, Labor, and Social Affairs and Health. The mission also met with representatives of research institutes, labor unions, and the employers' organization. The authorities published the mission's concluding remarks and intend to participate, for the second time, in the pilot project for the release of Article IV consultation staff reports.

- The mission comprised Mr. Artus (Head), Ms. Daseking, and Mr. Mesquita (all EU1). Mr. Lehmussaari, Executive Director, participated in the meetings.

- Finland has accepted the obligations of Article VIII, Sections 2, 3, and 4, and maintains an exchange system free of restrictions (Appendix I). Finland subscribes to the Special Data Dissemination Standard (SDDS) and meets the specifications for the coverage, periodicity, and timeliness of the SDDS data, and for the dissemination of advanee release calendars (Appendix II). Finland's provision of high-quality core data on a timely basis facilitates the conduct of effective surveillance, with extensive supplementary data published on the internet.

- The last Article IV consultation was concluded on October 8, 1999 (SUR/99/116). At that time, Directors commended the authorities for their impressive conduct of macroeconomic policies, notably in restraining public expenditure. They noted, nevertheless, that deeper structural reforms, particularly in the labor market, were called for to raise output and employment growth, curb demographic pressures on the public finances, and improve the flexibility of the economy under monetary union.

- In light of favorable economic conditions and broadly unchanged policy requirements prevailing in Finland, this report is kept brief, focusing on key issues only. 


\section{Background}

1. Finland has completed its recovery from the severe recession of the early $1990 \mathrm{~s}$ with the help of sound macroeconomic policies, and economic growth is now increasingly sustained by the sectors of the "new economy". Real GDP increased at an average annual rate of $4 \frac{1}{2}$ percent over the past three years, while inflationary pressures have remained largely absent (Table 1 and Figure 1). Fiscal policies anchored on firm expenditure restraint have moved the public finances back into a sizeable surplus, and the viability of the banking sector has been restored. The expansion has been led by a very dynamic "high tech" sector, which, while still accounting for only 3 percent of employment, is generating nearly a third of the growth in real GDP.

2. Finland weathered the 1998-99 emerging market crisis with only a mild slowdown in economic growth, and the near-term outlook for economic activity is favorable. After a temporary slowdown in the first half of 1999, economic growth picked up toward the end of the year, driven by a sharp recovery in exports. This expansion in exports should continue in 2000-2001 as external competitiveness remains strong and the growth of domestic demand accelerates in the rest of the euro area. Domestic demand should also expand rapidly in Finland, with consumer and business confidence comforted by favorable employment and profit developments. Both the authorities and the staff project solid economic growth of the order of 5 percent in 2000 and 4 percent in 2001, with risks assessed to be larger on the upside. Consumer price inflation has picked up in the first half of 2000 to an annual average of around 23/4 percent, with higher oil prices and housing costs accounting for some 1 and $1 / 2$ percentage points, respectively. The latter have also contributed to a rise in core inflation (excluding energy and seasonal food) from a low rate of just above 1 percent in 1999 to slightly below 2 percent in May 2000 - some $3 / 4$ percentage points above the euro-area average.

3. The main challenges for economic policy are now predominantly of a structural nature. In particular, (i) labor productivity is well below the euro-area average, and outside the high tech sector, productivity has increased at an annual rate of only 1.3 percent over the past three years; (ii) despite a significant fall in recent years, the unemployment rate at around 10 percent is high, even by European standards, and particularly excessive among the low-skilled (Figure 2); and (iii) the effective labor supply is limited by a low average retirement age of 59 years, which if not tackled, will significantly exacerbate the impending demographic shock (Box 1).

\section{Policy Discussions}

4. The discussions focussed on three main issues: the assessment of the cyclical position and risks; the appropriate fiscal strategy over the medium term; and complementary reform measures to ease demographic pressures, foster employment creation, and strengthen the growth potential of the economy. 
Figure 1. Finland: Selected Economic Indicators, 1990-2001
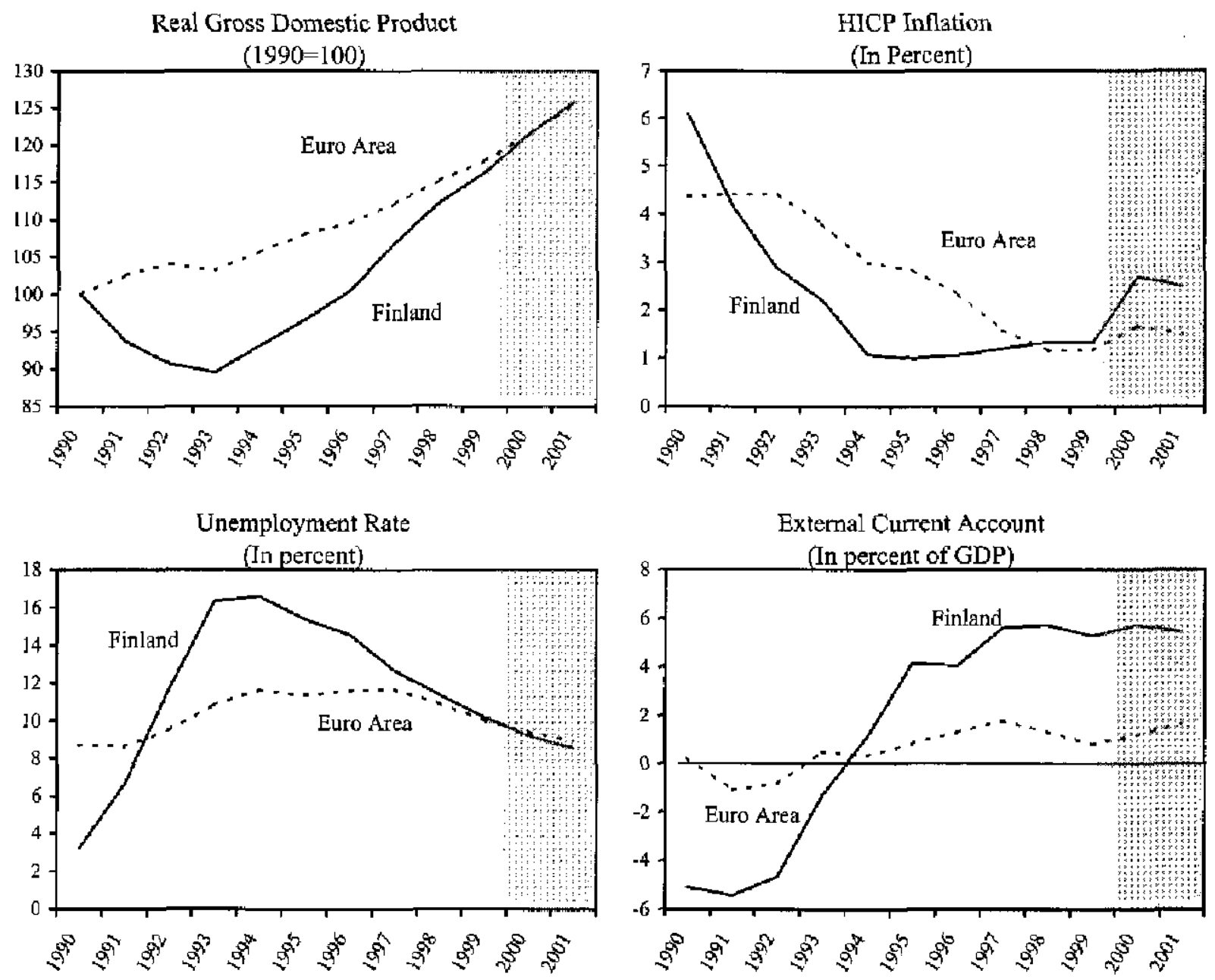

General Government Bạance

(In percent of GDP)

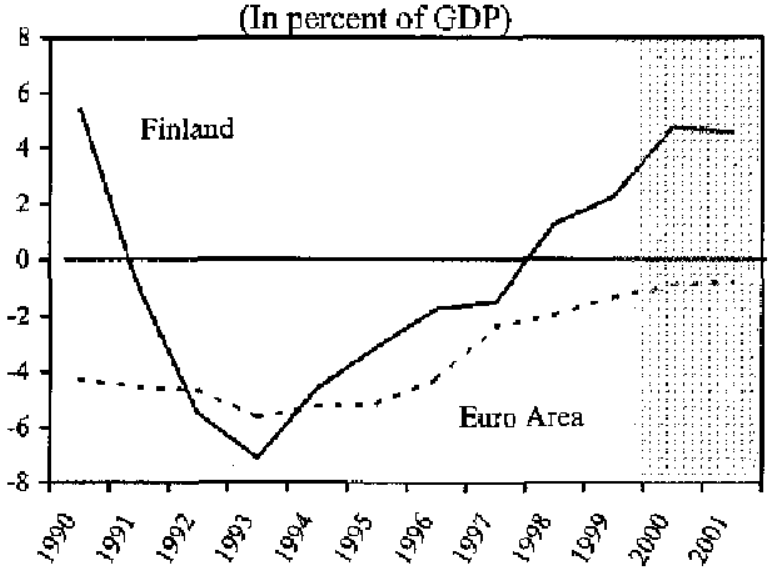

Real Domestic Demand $(1990=100)$

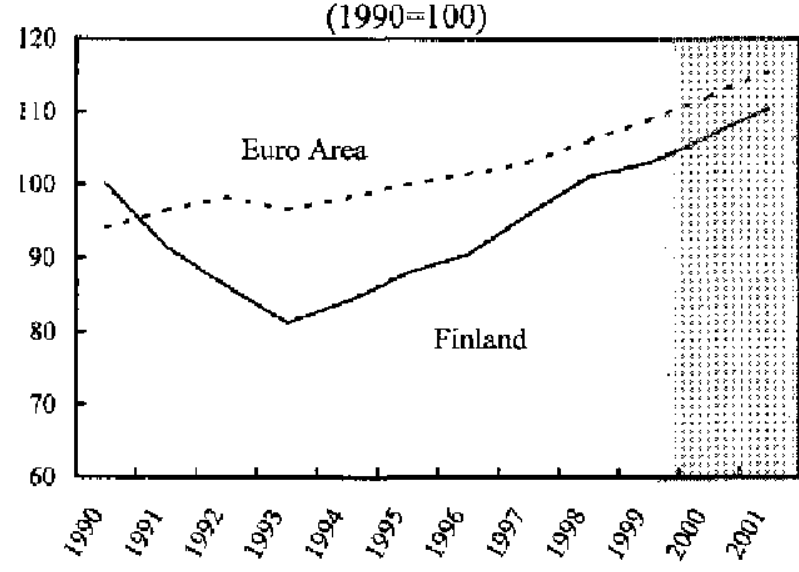

Sources: World Economic Outlook, European Central Bank; and staff estimates and projections. 
Figure 2, Finland: Labor Market Characteristics, 1987-99
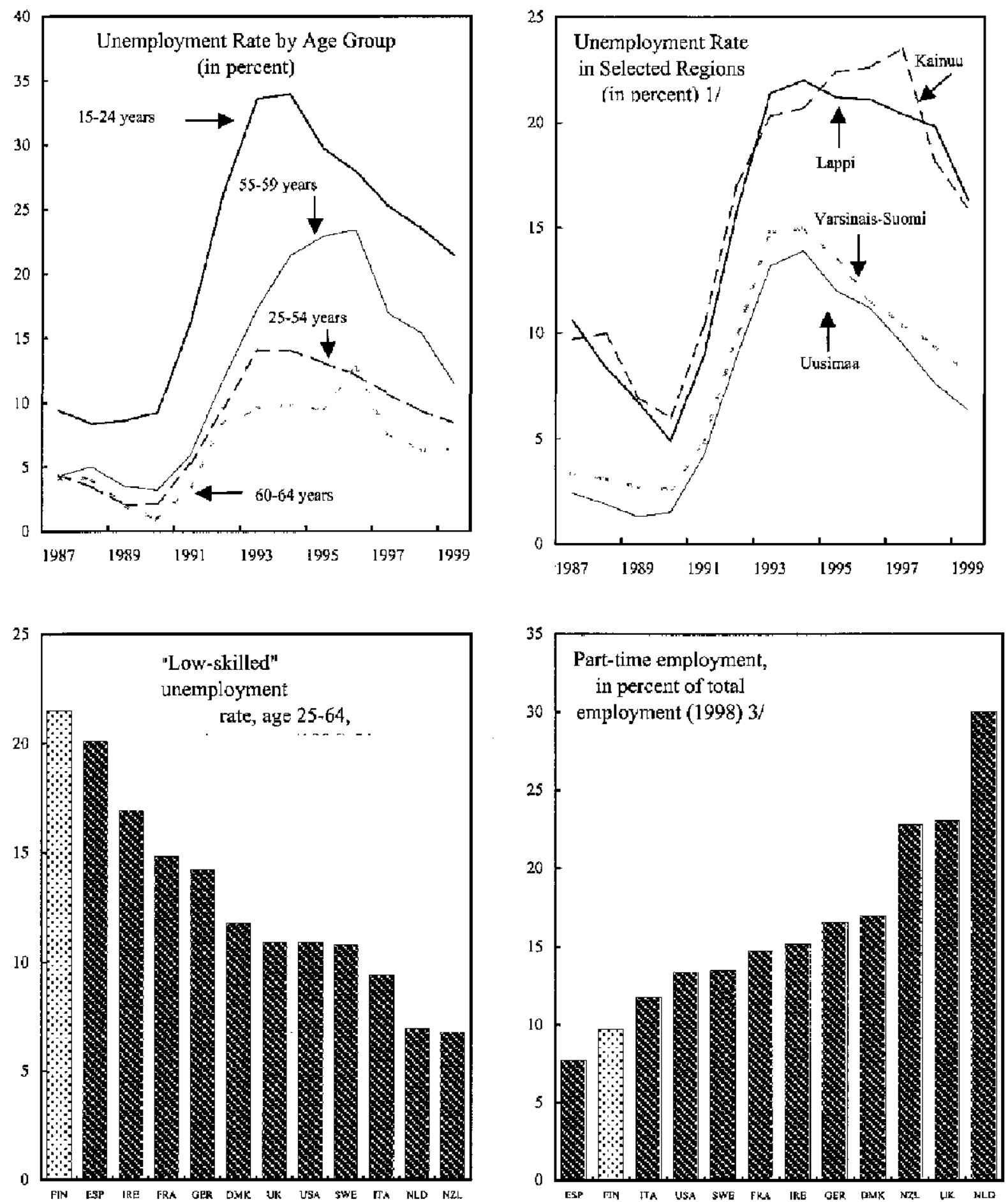

Sources: Fimish Labor Market Review; OECD Employment Outlook 1999; and staff estimates.

1/ Lappi and Kainuu are regions in the Northern part of the country; Uusimaa and Varsinais-Suomi are in the South, 2/ Defined as unemployment rate of people with less than upper secondary education. Data for New Zealand refers to 1997.

3/ Data for Ireland refers to 1997; data for United States is estimate for wage and salary workers only. 


\section{Box 1. The Fiscal Impact of Population Aging}

- The demographic shock in Finland will occur earlier than in most advanced economies, with the old-age dependency ratio (population aged 65 and over as a percent of the working-age population of 20-64) rising sharply from 2010 on and stabilizing at around 50 percent in 2035-50 roughly double the ratio of 1999.

- With regard to pension outlays, the situation is worsened by a low effective retirement age of 59, which, if unchanged, would not only advance the impact of the demographic shock but also increase its magnitude, with the number of people aged 59 and over, in proportion to the age group of $20-58$, projected to rise to mote than 70 percent by 2030 , compared with 40 percent in 1999 .

- In terms of the direct fiscal impact, measured by the increase in expenditures, the size of the pension shock is projected to be of the order of $4 / 2$ percentage points of GDP, if the effective retirement age remains unchanged, with growing health outlays projected to add another $1 \frac{1}{2}$ percentage points to public spending.

5. There was broad agreement between the authorities and the staff, that at present the Finnish economy was not overheating. Staff concurred with the authorities' assessment that, although economic growth in 2000 was outpacing its trend rate, the economy was currently operating at a broadly neutral cyclical position: the economy-wide vacancy rate was below 1 percent of the labor force; generalized cost-push pressures were subdued; and capacity utilization remained below peaks of recent years, with the shift in activity toward the high tech sector-where capacity was fully used but also expanding rapidly--likely boosting the average utilization rate at which capacity constraints become binding (Figure 3). Moreover, both the employment and participation rates, while on a rising trend in recent years, were well below their longer-term historical average, suggesting some room for further employment expansion before excessive wage pressures would be expected.

6. On the other hand, early warning signs were pointing to the likely emergence of labor market tensions, capacity constraints, and rising demand pressures over the coming years in the absence of further reforms. Labor shortages were growing in certain sectors, such as information technology and construction, and wage negotiations in 2000 had been more difficult than in earlier years. Also, there was agreement that the recent pick up in inflation needed to be monitored carefully. Even with wage moderation, core inflation could exceed 2 percent in 2001, possibly triggering higher wage demands in the following years. Notwithstanding the recent $\mathrm{ECB}$ interest rates hikes $-\cdots$ which had contributed to a slowdown in domestic credit expansion from an average of $12 \frac{1}{2}$ percent in 1999 to around 7 percent in May 2000-monetary conditions in Finland were accommodative (Figure 4). This was partly a reflection of its somewhat advanced cyclical position relative to the euro area average, but also of a strong impact from the weak euro, due to Finland's comparatively large share of trade (some 65 percent) with countries outside the euro area. Looking ahead, monetary conditions were likely to tighten with an anticipated cyclical convergence within the euro area and an expected recovery of the euro. Finally, a substantial rise in asset prices over the past years - notwithstanding the high volatility in the stock market- had increased the scope 
Figure 3. Finland: Cyclical Indicators, 1985-2000 1/

Monthly Indicator for Total Output

$(1990=100)$

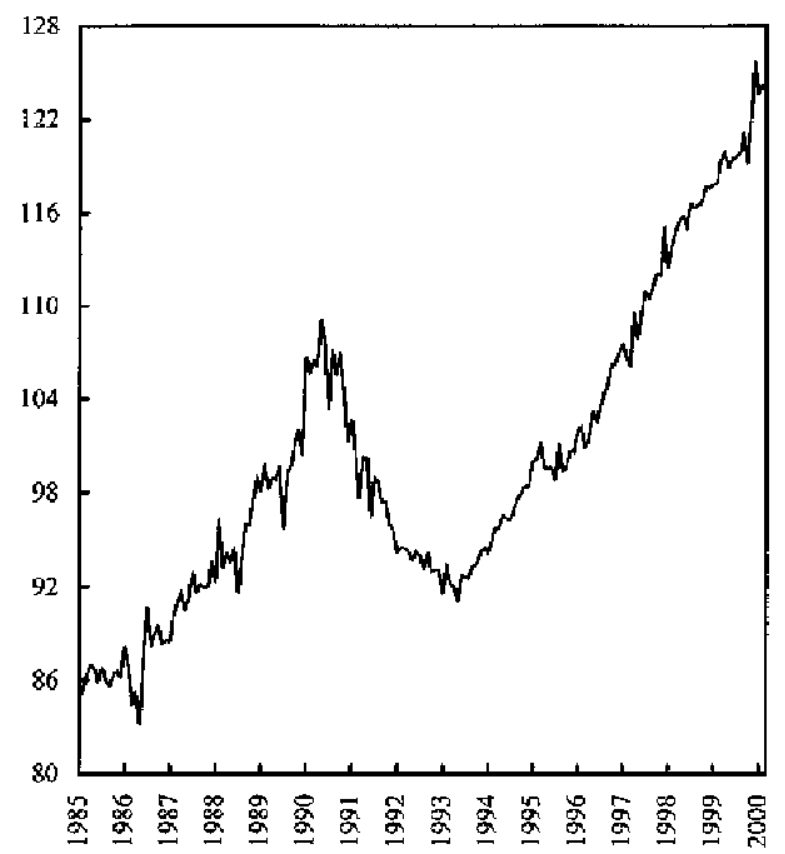

Capacity Utilization in Manufacturing and Economy Wide Vacancies

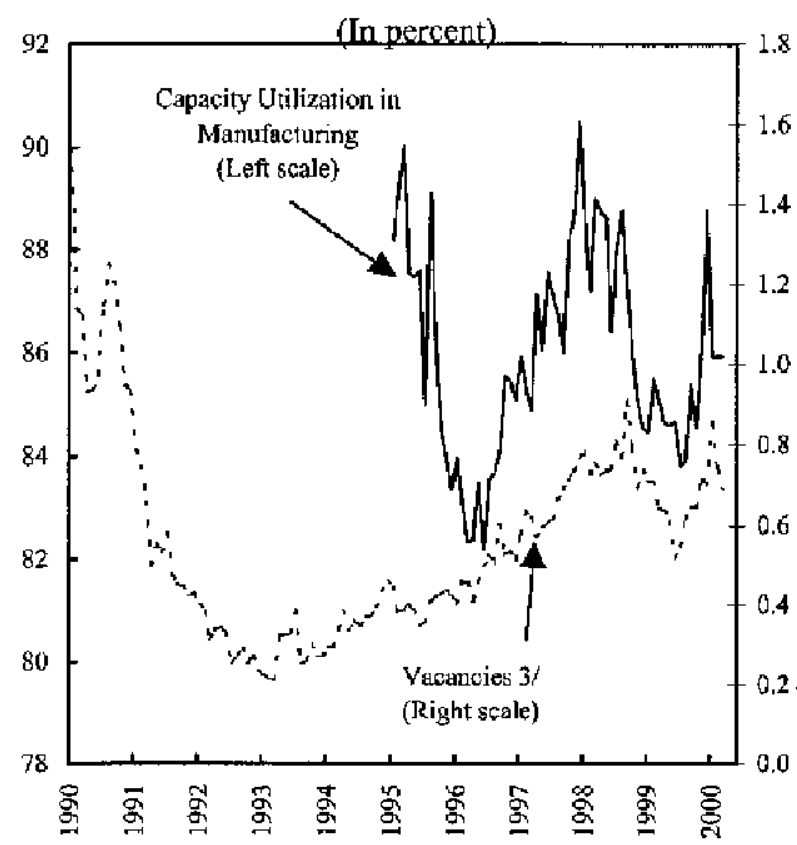

Industrial Output by Sector

$(1995=100)$

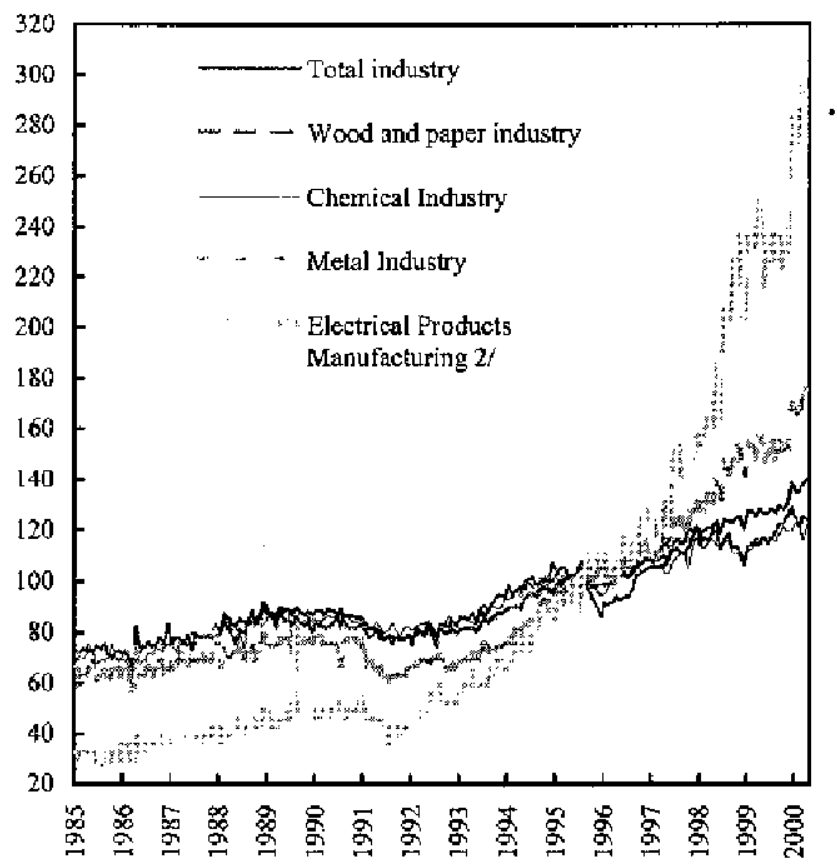

Asset Prices $(1995=100)$

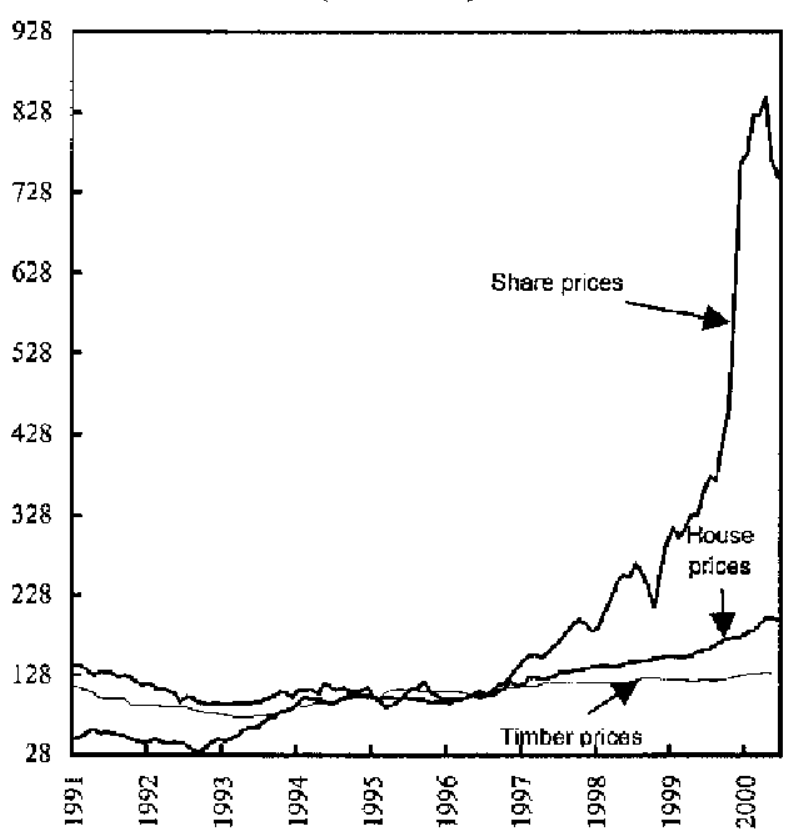

Sources: ETLA and staff estimates.

1/ Seasonally adjusted; shorter periods for certain indicators reflects the lack of data availability.

2/ Included in metal industry.

$3 /$ In percent of labor force. 
Figure 4. Finland: Monetary Indicators, 1995-2000

Nominal Interest Rates

(In percent)

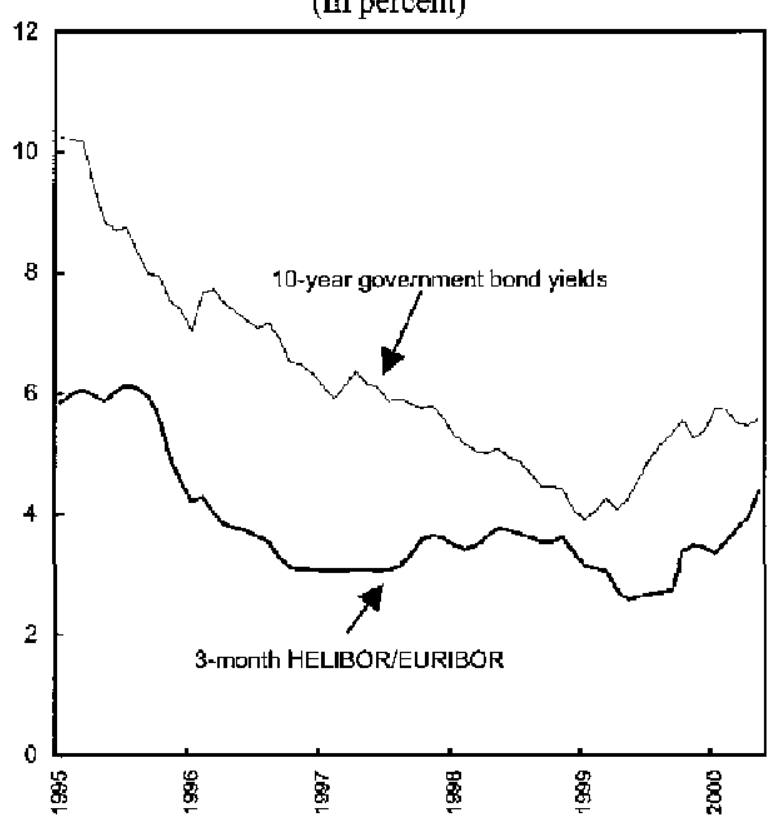

Real Effective Exchange Rates

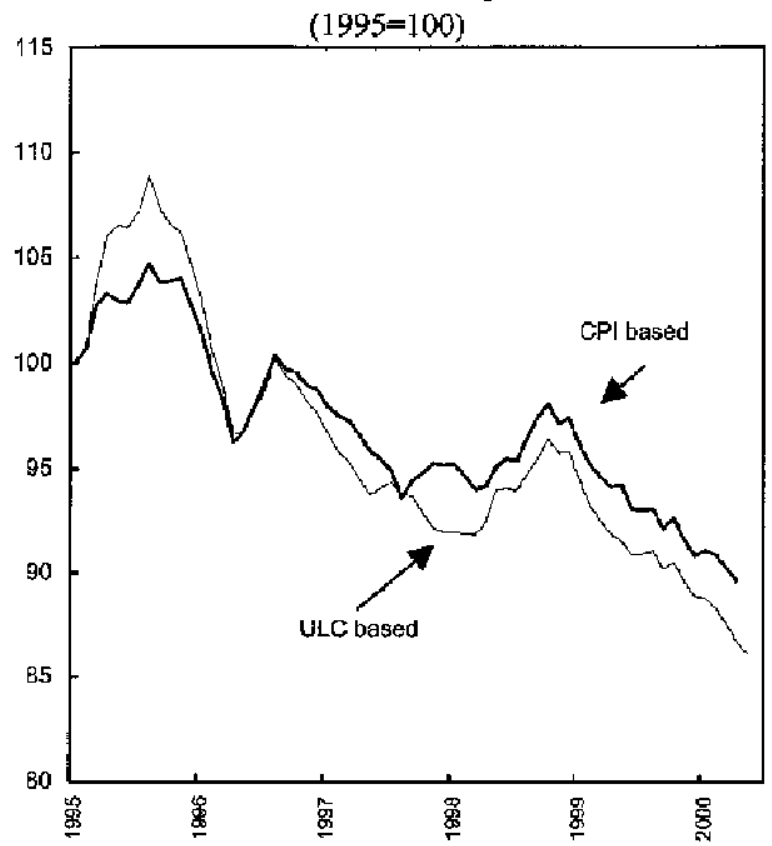

Real Interest Rates $/ /$

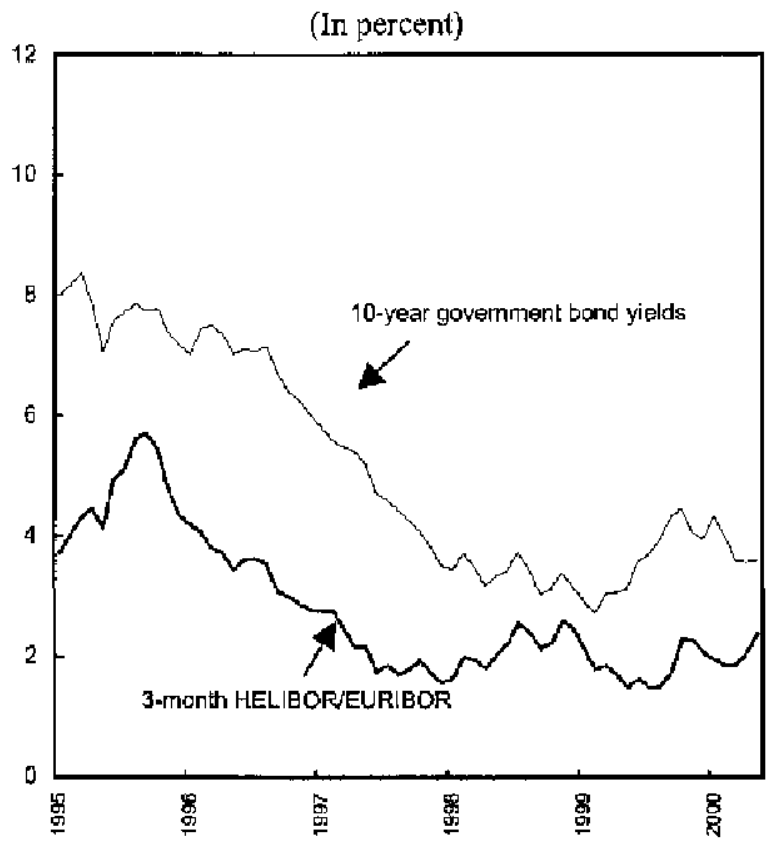

Monetary Conditions Index $2 /$

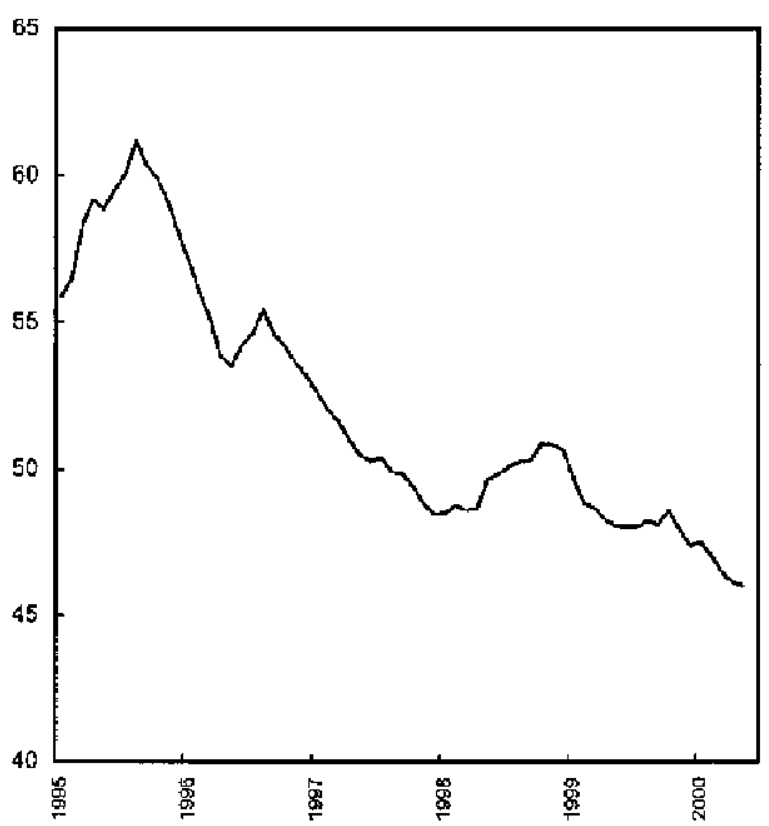

Sources: ETLA, Bank of Finland, Eurostat, and staff estitnates.

1/ Derived on the basis of contemporaneous consumer price inflation through 1995 and core inflation (Eurostat definition, excluding price changes of energy products and seasonal food) thereafter.

2/ Based on staff estimates, using weights for real short-term and long-term interest rates and the real effective exchange rate (ULC based) of one-third each. 
for wealth effects feeding into higher aggregate demand. ${ }^{1}$ At the same time, the rapid increase in lending, combined with the rise in asset prices, had made banks more vulnerable to sudden reversals in market developments. Although the financial sector appeared currently sound (Table 3), the mission encouraged the authorities to closely monitor banks' growing exposure to the real estate market and to perform stress tests, assessing the potential implications of a combined collapse of stock market and real-estate prices. Overall, there was broad agreement between the staff and the authorities that to forestall an overheating of the economy over the coming years, fiscal and structural policies needed to focus on strengthening the flexibility and supply response of the economy.

7. The authorities confirmed that their medium-term fiscal strategy was based on expenditure restraint generating sizeable fiscal surpluses, while providing scope for tax cuts on labor income. The central government's expenditure plans through 2003 keep real spending broadly at the 1999 level. Based on the September 1999 update of Finland's Stability Program, this was projected to reduce the public expenditure ratio by $31 / 2$ percentage points of GDP between 1999 and 2003, which would be sufficient to bring the share of public spending in GDP below pre-crisis levels (Table 2, lower panel). ${ }^{2}$ The central government position was projected to be in surplus throughout the $2000-03$ period, notwithstanding tax cuts on labor income of Fmk 10-11 billion (some 1/2 percent of 1999 GDP), of which Fmk 2.5 billion ( 0.3 percent of GDP) was included in the 2000 budget. Bolstered by the social security funds, the general government surplus was forecasted to rise to $4 \frac{3 / 4}{4}$ percent of GDP by 2003 , thus providing a cushion for the fiscal impact of population aging over the coming decades. Encouraged by strong economic growth and buoyant revenues, the government recently announced its intention to increase the size of tax cuts, subject to continued wage moderation, but both the magnitude and the timing of the planned reductions remain to be decided.

8. The mission supported the authorities'plans and encouraged them to be bold in their tax-cutting endeavor, suggesting an overall reduction in income taxes and social security contributions of about $2^{1 / 4}$ percentage points of GDP, spread uniformly over the 2001-03 period, and designed to combine targeted relief for lower income groups with across-the-bourd reductions. Incorporating revised official projections for revenues and

\footnotetext{
' Share prices rose by about 160 percent between end-1998 and end-1999-boosting households' financial wealth by 40 percent-and since the beginning of 2000 , the Helsinki Stock Exchange index has shown significant volatility around a historically high plateau. Housing prices have also risen substantially, at around 10 percent annually, in the last 2-3 years, and have accelerated further in recent months, particularly in the Helsinki area.

2 The EU Council of Ministers welcomed Finland's strong budgetary position and its plans for structural reforms, adding that further fiscal and labor market reforms were needed to reduce the current heavy overall taxation and social contribution burden on labor. Revised medium-term projections are expected to be published in September 2000.
} 
expenditures in 2000-01 and assuming average potential output growth of about $3 \frac{1 / 2}{2}$ percent during 2001-03, this would still be consistent with keeping a structural surplus in the central government finances (Table 2, upper panel). The suggested tax cuts would imply a fiscal stance over the $2001-03$ period that was only marginally stimulative, measured by the change in the structural primary balance, when taking into account special factors in $2000 / 01{ }^{3}$ The authorities agreed with the mission that the risks associated with a marginal fiscal stimulus in 2001-03 - already somewhat alleviated by an expected tightening of monetary conditions - -was acceptable in light of the lasting benefits of a substantial reduction in the tax wedge, provided it was complemented by other structural measures to curb inflationary pressures (see below). As to the composition of tax cuts, the mission supported the authorities' general strategy of combining targeted relief for low-income groups (e.g., through a reduction in social security contributions for low-paid jobs) with across-the-board reductions in high marginal rates, to provide a balance between the two goals of reducing high unemployment among the low-skilled and affecting work (and residence) decisions on a wider scale.

9. There was full agreement between the staff and the authorities that in order to both avoid an emergence of inflationary pressures and adjust to the impending demographic shock, the suggested fiscal policy stance needed to be complemented by other measures on the structural front to expand the effective labor supply and enhance the flexibility of the economy. In this context, the mission supported the authorities' goals of raising the effective retirement age by $2-3$ years and the employment rate to 70 percent over the medium term, while strengthening further the competitive environment. Success in these areas, would provide room for a more sizeable reduction in the tax wedge, and could have powerful implications for employment, economic growth, and the long-run sustainability of the public finances (Appendix III). Current policies, however, were unlikely to bring about the desired results, and the mission urged actions in the following areas:

- Financial incentives for early retirement need to be removed, in order to encourage a longer active working life. Reforms should include the discontinuation of various subsidized early retirement schemes, such as unemployment and part-time pensions, and a move toward a closer relationship between pension benefits and life-time contributions. With large cohorts at risk of leaving the labor force prematurely over the next five to ten years, prompt action is needed.

\footnotetext{
${ }^{3}$ The special factors in $2000 / 01$ refer to the fact that the decline in revenues in 2001 reflects, in part, the one-off nature of taxes on extraordinary capital gains in 2000 , related to intercompany share holdings, and equivalent to about 1 percent of GDP. Given the expected transitory nature of these taxes and the presumption that they would not entail a significant withdrawal (and subsequent expansion) of aggregate demand, they have not been included in the measure of the structural primary balance in Table 2 .
} 
- Greater labor market flexibility and improved incentives to create and seek jobs are needed, particularly at the low-skill level, where unemployment is most severe. Reductions in the tax wedge will help, but larger wage differentiation, in line with diverse productivity developments, is crucial, as well as a more incentive-oriented unemployment benefits system, conditioned on job search and with declining payments over time.

- Further product market reforms that encourage competition and business creation are warranted to dampen inflationary risks and foster overall productivity growth, with potentially large spill-over effects from an expansion of the internet-based "new economy". There is also a need to improve the functioning of the land and housing market in growth centers, in order to facilitate labor mobility.

10. The authorities acknowledged the need for further structural reforms, with an improved supply response and growth potential of the economy providing room for an expansion of demand supported by tax cuts. They were hopeful that the publication of the mission's concluding remarks and the staff report would stimulate domestic debate and broaden the support for reform measures that, by fostering inclusion and economic growth, were indeed crucial for preserving the welfare state, but too often misinterpreted as attempting the opposite.

\section{Staff APPRAisal}

11. Thanks to sound macroeconomic policies, Finland has fully recovered from the depression of the early 1990s, and is engaged in a new phase of economic expansion. Rapid economic growth over the past years is set to continue in $2000-01$, supported by a very dynamic high tech sector. The public finances are back in surplus; the viability of the banking sector has been restored; and so far, inflationary pressures have been subdued, notwithstanding accommodative monetary conditions, supported by a very competitive exchange rate.

\section{Nonetheless, serious problems remain on the structural front, that if not tackled} promptly, could undermine the prospects for robust long-term growth and hinder Finland's adjustment to the impending demographic shock. In particular, outside the high tech sector, productivity growth is rather low, and a high rate of structural unemployment, combined with a low average retirement age, limit the effective labor supply. These problems are not unrelated to the heavy tax burden and to persistent rigidities in procuct and labor markets. Moreover, while overheating is not an imminent risk, price and wage pressures could emerge over the coming years. With a shrinking pool of cyclical unemployment to be absorbed, the growth potential of the economy could be sharply curtailed, unless labor market tensions and capacity constraints are alleviated by decisive measures to improve the flexibility and the supply response of the economy. 
13. On the fiscal front, continued restraint on the growth of public expenditures is crucial, but needs to be complemented by a significant reduction in the heavy tax burden on labor income. The government's medium-term expenditure plans continue the process of fiscal consolidation, with sizeable surpluses cushioning the fiscal impact of growing demographic pressures, while providing scope for reductions in income taxes and social security contributions. With the favorable outlook in public finances, the government's intention of augmenting earlier announced tax cuts is welcome, and an overall reduction in the tax wedge of about $2 \% / 4$ percentage points of GDP should be feasible over the $2001-03$ period. This would be consistent with maintaining a sizeable structural surplus and imply an almost neutral fiscal stance at a time when monetary conditions in the euro area are likely to tighten. As to the composition of tax cuts, a mixed approach, combining targeted relief for low-income groups with across-the-board reductions in marginal rates, would be most effective in encouraging job creation at the low-skill level, while affecting performance incentives and residence decisions on a wider scale.

14. To avoid an emergence of inflationary pressures and adjust to the dentographic challenges, the macroeconomic policy stance needs to be complemented by other measures on the structural front that help expand the effective labor supply and enhance the supply response of the economy. In particular, the existing schemes for subsidized early retirement, which were established during the depression period of the early $1990 \mathrm{~s}$, need to be abolished to promote the reintegration of the age group of 55-65 years into the active labor force. Alse, a closer link between pension benefits and life-contributions will be crucial to foster both work incentives and intergenerational faimess. In the labor market, social partners need to allow for greater wage differentiation, commensurate with diverse productivity developments, in order to strengthen the demand for low-skilled labor. At the same time, the unemployment benefits system should be redesigned to enhance incentives for a quick reintegration into the active workforce. Finally, to dampen inflationary risks and foster economy-wide productivity growth, further reforms of product markets are crucial, including the removal of rigidities in land and housing markets, in order to promote labor mobility.

15. It is proposed that the next consultation take place on the standard 12-month cycle. 
$-12$

Table 1. Finland: Main Economic Indicators, 1997-2001

\begin{tabular}{|c|c|c|c|c|c|}
\hline & 1997 & 1998 & $\begin{array}{c}1999 \\
\text { Prel. }\end{array}$ & $\begin{array}{r}2000 \\
\text { Proj. }\end{array}$ & $\begin{array}{r}2001 \\
\text { Proj. }\end{array}$ \\
\hline & \multicolumn{5}{|c|}{ (Percentage change, unless otherwise indicaled) } \\
\hline \multicolumn{6}{|l|}{ Output and demand (volumes) } \\
\hline GDP & 6.3 & 5.0 & 3.5 & 5.0 & 4.0 \\
\hline Domestic demand & 6.0 & 5.4 & 1.9 & 3.6 & 3.5 \\
\hline Consumption & 3.7 & 3.7 & 2.1 & 2.3 & 2.8 \\
\hline Private consumption & 3.5 & 4.6 & 2.9 & 2.9 & 3.7 \\
\hline Public consumption & 4.1 & 1.5 & 0.3 & 0.8 & 0.5 \\
\hline Gross fixed capital formation & 11,9 & 7.8 & 4.8 & 8.6 & 6.0 \\
\hline Private investment & 11.3 & 9.6 & 7.0 & 6.5 & 6.5 \\
\hline Public investrnent & 15.0 & -0.4 & -6.3 & -0.8 & -2.8 \\
\hline Export of goods and services & 14.1 & 9.3 & 7.4 & 9.4 & 7.0 \\
\hline Import of goods and services & 11.3 & 8.5 & 3.4 & 7.3 & 6.9 \\
\hline Foreign contribution to growth (in percent of GDP) & 2.0 & 1.1 & 2.0 & 1.8 & 0.9 \\
\hline \multicolumn{6}{|l|}{ Prices and costs } \\
\hline Harmonized CPI & 1.2 & 1.3 & 1.3 & 2.7 & 2.5 \\
\hline GDP deflator & 2.1 & 2.9 & 1.0 & 2.0 & 1.4 \\
\hline Terms of trade & .2 .6 & 2.5 & -5.0 & -2.9 & -1.6 \\
\hline Unit labor cost, manufacturing & -4.3 & -1.3 & 0.5 & -0.5 & 1.7 \\
\hline \multicolumn{6}{|l|}{ Labor market } \\
\hline Labor force & -0.2 & 1.0 & 2.0 & 0.3 & 0.2 \\
\hline Employment & 2.0 & 2.4 & 3.3 & 1.3 & 1.0 \\
\hline Unemployment rate (in percent) & 12.7 & 11.4 & 10.2 & 9.3 & 8.6 \\
\hline \multicolumn{6}{|l|}{ Output gap } \\
\hline Output gap (in percent of potential output) $1 /$ & -2.3 & -1.1 & -1.2 & -0.1 & 0.3 \\
\hline Growth in potential output & 3.6 & 3.7 & 3.7 & 3.8 & 3.5 \\
\hline \multicolumn{6}{|l|}{ Money and interest ṛates } \\
\hline M3 (growth rate in percent, end-of-period) $2 /$ & 7,2 & 2.5 & 6.0 & 7.3 & $\ldots$ \\
\hline Domestic credit (growth rate in percent, end-of-period) $3 /$ & 10 & 11.9 & 10.6 & 7.2 & $\ldots$ \\
\hline 3-month money market rate (in percent) $4 /$ & 3.2 & 3.6 & 3.0 & 3.9 & $\ldots$ \\
\hline \multirow[t]{2}{*}{ 10-year government bonds yield (in percent) 4} & 6.0 & 4.8 & 4.7 & 5.6 & $\ldots$ \\
\hline & \multicolumn{5}{|c|}{ (In percent of GDP, unless otherwise indicated) } \\
\hline \multicolumn{6}{|l|}{ National savings, investment, and income } \\
\hline Gross national saving & 24.1 & 24.7 & 25.2 & 26.5 & 26.6 \\
\hline Gross domestic iflvestment & 18.5 & 19.0 & 19.9 & 20.8 & 21.2 \\
\hline Private saving & 22.4 & 20.6 & 20.2 & 19.1 & 19.5 \\
\hline Household saving as percent of disposable income & 4.4 & 3.9 & 4.6 & 4.3 & 4.4 \\
\hline Private investment & 15.3 & 16.2 & 17.2 & 18.2 & 18.6 \\
\hline Govemment savings surplus & -1.5 & 1.3 & 2.3 & 4.8 & 4.6 \\
\hline Household's real dispasable income (increase in percent) & 6.0 & 4.1 & 3.7 & 3.6 & 5.0 \\
\hline \multicolumn{6}{|l|}{ Balance of payments } \\
\hline Current account balance & 5.6 & 5.7 & 5.3 & 5.7 & 5.4 \\
\hline Trade batance & 9.5 & 9.7 & 9.1 & 9.5 & 9.3 \\
\hline Net iricrnational investment position & -41.0 & -71.9 & -175.6 & -165.4 & -1579 \\
\hline Net external debt, excluding FDI and shares & 28.3 & 26.3 & 19.8 & 12.8 & 6.7 \\
\hline \multicolumn{6}{|l|}{ Memorandum item: } \\
\hline Nominal GDP (in billions of Fmk) & 635.5 & 686.7 & 718.0 & 768.9 & 810.8 \\
\hline
\end{tabular}

Sources: Bank of Finland; ETLA; and staff projections.

I/ A negative value indicates a level of potential output that is larger than actual GDP.

2/ From 1999 onward, Finnish contribution to curo area M3. For 2000, 12-month increase through May.

3/ Lending by Finnish banks to the domestic sector. For 2000, 12-month increase through May.

4/ For 2000 , average through June. 
Table 2. Finland: General Government Finances, 1999-2003

(In percent of GDP, unless otherwise indicated)

\begin{tabular}{|c|c|c|c|c|c|c|}
\hline & \multirow[b]{2}{*}{$\begin{array}{l}1999 \\
\text { Prel. }\end{array}$} & \multirow[b]{2}{*}{$\begin{array}{r}2000 \\
\text { Proj. } \mathrm{l} /\end{array}$} & \multirow[b]{2}{*}{$\begin{array}{r}2001 \\
\text { Proj. } 1 /\end{array}$} & \multicolumn{3}{|c|}{ Staff projections: fiscal reform scenario $2 /$} \\
\hline & & & & 2001 & 2002 & 2003 \\
\hline Revenue $3 /$ & 49.5 & 50.1 & 48.6 & 48.1 & 47.3 & 46.5 \\
\hline Taxes $4 /$ & 45.9 & 46.2 & 45.0 & 44.6 & 43.8 & 43.0 \\
\hline Other revenue & 3.6 & 3.8 & 3.6 & 3.6 & 3.5 & 3.5 \\
\hline o/w interest & 2.1 & 2.0 & 2.0 & 2.0 & 2.0 & 2.0 \\
\hline Expenditure $3 / 5 /$ & 47.3 & 45.3 & 44.0 & 44.0 & 43.2 & 42.4 \\
\hline Primary expenditure 5/ & 43.7 & 42.0 & 41.0 & 41.0 & 40.4 & 39.9 \\
\hline Interest payments & 3.6 & 3.4 & 3.0 & 3.0 & 2.8 & 2.5 \\
\hline Balence 3 & 2.3 & 4.8 & 4.6 & 4.2 & 4.1 & 4.1 \\
\hline Central goverminęnt & -0.6 & 1.6 & 1,4 & 0.9 & 0.6 & 0.4 \\
\hline Local governments & -0.2 & 0.2 & 0.1 & 0.1 & 0.5 & 0.6 \\
\hline Social security funds & 3.1 & 3.1 & 3.1 & 3.1 & 3.0 & 3.2 \\
\hline \multicolumn{7}{|l|}{ Memarandum items: } \\
\hline Primary balance $6 /$ & 3.7 & 6.1 & 5.6 & 5.2 & 5.0 & 4.7 \\
\hline Structural balançe (in percent of potential output) $7 /$ & 3.0 & 3.881 & 4.4 & 4.0 & 4.1 & 4.1 \\
\hline Of which: central govemment $7 /$ & -0.1 & 0.681 & 1.2 & 0.8 & 0.6 & 0.4 \\
\hline Structural primary balance (in percent of potential output) $6 / 7 /$ & 4.5 & 5.281 & 5.4 & 5.0 & 4.9 & 4.7 \\
\hline Output gap (in percent of potential output) $7 /$ & -1.2 & -0.1 & 0.3 & 0.3 & $\ldots$ & $\ldots$ \\
\hline Potential output growth (volume) $7 t$ & 3.7 & 3.8 & 3.5 & 3.5 & 3.5 & 3.3 \\
\hline \multicolumn{7}{|c|}{ Authorities' Projections Presented in September 1999 Update of S1ability Program 9/ } \\
\hline Revenue & 51.2 & 51.4 & 50.4 & $\ldots$ & 49.9 & 49.3 \\
\hline Expenditure 5/ & 48.1 & 46.7 & 46.2 & $\ldots$ & 45.3 & 44.6 \\
\hline Balance & 3.1 & 4.7 & 4,2 & $\ldots$ & A.6 & 4.7 \\
\hline Central govenanent & $-0,2$ & 0.7 & 0.5 & $\ldots$ & 1.1 & 1.3 \\
\hline Local governments & 0.1 & 0.3 & 0.2 & $\ldots$ & 0.1 & 0.1 \\
\hline Social security fiunds & 3.2 & 3.7 & 3.5 & $\ldots$ & 3.4 & 3.3 \\
\hline
\end{tabular}

Sources: Ministry of Finance, Stability Program for Finland, Sept. 1999 Update; and staff projections.

1/ Authorities' and staff projections, assuming no augmentation of original tax cut plans.

2/ Incorporates the impact of suggested cuts in taxes and social security contributions equivalent to $2 / 4$ percentage points of GDP over 2001-03.

3/ For 2002 and 2003, revenues, expenditures, and balances are projected on a cyclically adjusted basis, expressed in percent of potential output,

$4 /$ Includes taxes and social security contributions.

5/ Includes capital expenditure, depreciation, and net capital transfers.

6/ Prinary balance is defined as noninterest revenue minus noninterest expenditure.

7/ Staff projections; the authorities do not publish official projections of potential output and structural balances.

8/ Excludes revenues from one-off taxes on extraordinary capital gain:s, equivalent to 1 percent of GDP, which are treated as cyclical for the purpose of assessine the discretionary fiscal irmpulse.

9/ Authorities' projections of September 1999 incorporate original tax cut plans. 
Table 3. Finland: Indicators of Financial and Banking Sector Vulnerability, 1996-2000

\begin{tabular}{|c|c|c|c|c|c|}
\hline & 1996 & 1997 & 1998 & 1999 & 2000 \\
\hline & & & & Prcl. & Prel. \\
\hline \multicolumn{6}{|l|}{ Overall financial indicators } \\
\hline General government debt (EMU definition, in percent of GDP) & 56.6 & 53.7 & 48.3 & 47.1 & $\ldots$ \\
\hline Central govenment debt (in percent of GDP) & 67.5 & 65.8 & 62.2 & 57.2 & $\ldots$ \\
\hline Total corporate sector debt (in percent of GDP) & 53.7 & 48.7 & 46.2 & 48.2 & $\ldots$ \\
\hline Total bousehold debt (in percent of GDP) & 26.6 & 24.9 & 24.9 & 26.3 & $\ldots$ \\
\hline Broud money (percent change, end-of-period) $1 /$ & -1.3 & 7.2 & 2.5 & 6.0 & 7.331 \\
\hline Outstanding credit to nonfinancial private sector (percent change, e.o.p.) 2f & 0.5 & -1.0 & 11,1 & 13.9 & 6.93 \\
\hline Of which housing loans (percent change, c.o.p.) & 1.3 & 3.5 & 13.1 & 15.8 & $13.73 \pi$ \\
\hline Housing loans in percent of total lending to nonfinancial private sector $2 f$ & 38.8 & 40.5 & 41.3 & 41.9 & $43.33 \pi$ \\
\hline 3-month money market rate (nominal average, in percent) & 3.6 & 32 & 3.6 & 3.0 & 3.94 \\
\hline Deflated by core inflation index & 3.5 & 2.0 & 2.2 & 1.9 & 1.94 \\
\hline Layear government bond yield (nominal average, in percent) & 7.1 & 6,0 & 4.8 & 4.7 & 5.64 \\
\hline Deflated by core inllation index & 7.0 & 4.7 & 3.4 & 3.6 & 3.54 \\
\hline Change in stock market index (in percent, e.o.p.) & 37.7 & 35.1 & 58.8 & 162.0 & $107.95 f$ \\
\hline Change in housing price index (in percent, e.o.p.) & 19.0 & 21.9 & 9.5 & 16.2 & $22.65 t$ \\
\hline Banking sector indicators & & & & & $\ldots$ \\
\hline Non-performing assets / total assets (in percent) & 2.1 & 1.3 & 1.0 & 0.7 & 0.761 \\
\hline Non-performing assets / claims of the public (in percent) & 4.0 & 2.4 & 1.6 & 1.3 & $(.46)$ \\
\hline Risk-based capital asset ratio (capital in percent of risk-wcighted assets, e.o.p & $1 \mathrm{l} .4$ & 11.8 & 11.1 & 11.9 & $\ldots$ \\
\hline Interest rate margin (average lending minus deposit rate) & 4.1 & 4.3 & 4.0 & 3.5 & 3.97 \\
\hline \multicolumn{6}{|l|}{ Memorandum itom: } \\
\hline Core inflation (harmonized, excluding energy and seasonal food) & 0.1 & 1.2 & 1.4 & 1.1 & $2.08 j$ \\
\hline
\end{tabular}

Sources: Bank of Finland, The Finnish Rankers' Association, and staff estimates.

I/ From 1999 onward, Finnish contribution to euro area M3.

2/ Euro-denominated lending only, which accounted for about 98 percent of total lending in 1999.

3/ 12 -month increase at end-May 2000.

4/ Average through June 2000, deflated by core inflation index of May,

S/ 12 -month increase, as of end-June 2000.

6/ As of end-March 2000.

T/ Average through May 2000.

8/ Annual increașe in May 2000. 
Finland: Fund Relations

(As of June 30, 2000)

I. Membership Status: Joined 1/14/48; Article VIII.

II. General Resources Account:

Percent

SDR Million

Quota

Quota

$1,263.80$

100.0

Fund holdings of currency

872.63

69.0

Reserve position in Fund

391.19

31.0

III. SDR Department:

Percent

SDR Million

Allocation

Net cumulative allocation

142.69

100,0 Holdings

174.43

122.2

IV. Outstanding Purchases and Loans: None

V. Financial Arrangements: None

VI. Projected Obligations to Fund: None

VII. Exchange Rate Arrangements

1. Finland is a founding member of EMU, with a euro conversion rate of Finnish markka (Fmk) 5.94573. Finland has accepted the obligations of Article VIII and maintains an exchange system that is free of restrictions on payments and transfers of current international transactions. In accordance with Executive Board Decision No. 144-(52/51), Finland notified the Fund on September 5, 1990 and July 6, 1992 of exchange restrictions pursuant to UN Security Council Resolutions against Iraq and the Federal Republic of Yugoslavia (Serbia/Montenegro), respectively. On July 27, 1995, Finland also notified the Fund of exchange restrictions imposed against Libya, and of changes in the exchange restrictions pursuant to UN Security Council Resolutions on Iraq and the Federal Republic of Yugoslavia (Serbia/Montenegro) as well as on certain areas in the Republic of Bosnia and Herzegovina. Finland has since removed restrictions imposed against certain areas of the Republic of Croatia, the Republic of Bosnia and Herzegovina, and the Federal Republic of Yugoslavia (except for the prohibition on the satisfying of certain claims). The UN Security Council Resolution on food for oil (Iraq) was implemented in December 1996. 
Finland: Core Statistical Indicators

(As of June 30, 2000)

\begin{tabular}{|c|c|c|c|c|c|c|c|c|c|c|c|}
\hline & $\begin{array}{c}\text { Exchange } \\
\text { Rates }\end{array}$ & $\begin{array}{c}\text { Inter- } \\
\text { national } \\
\text { Reserves }\end{array}$ & $\begin{array}{l}\text { Central } \\
\text { Bank } \\
\text { Balance } \\
\text { Sheet } \\
\end{array}$ & $\begin{array}{c}\text { Reserve/ } \\
\text { Base } \\
\text { Money }\end{array}$ & $\begin{array}{c}\text { Broad } \\
\text { Money }\end{array}$ & $\begin{array}{c}\text { Interest } \\
\text { Rates }\end{array}$ & $\begin{array}{l}\text { Consumer } \\
\text { Price } \\
\text { Index } \\
\end{array}$ & $\begin{array}{l}\text { Exports/ } \\
\text { Imports }\end{array}$ & $\begin{array}{l}\text { Current } \\
\text { Account } \\
\text { Balance }\end{array}$ & $\begin{array}{c}\text { Central } \\
\text { Government } \\
\text { Balance }\end{array}$ & GDP \\
\hline $\begin{array}{l}\text { Date of Latest } \\
\text { Observation }\end{array}$ & Jun. 30 & May 26 & May 26 & May 26 & May 26 & Jun. 30 & May & April & April & May & $\mathrm{QL}, 2000$ \\
\hline Date Received & Jun. 30 & May 30 & May 30 & May 30 & May 30 & Jun. 30 & Jun. 14 & Jun. 14 & Jarn. 14 & Jun. 28 & Jun. 27 \\
\hline $\begin{array}{l}\text { Frequency of } \\
\text { Data }\end{array}$ & Daily & Montbly & Monthly & Monthly & Monthly & Daily & Monthly & Monthly & Monthly & Monthly & Quarterly \\
\hline $\begin{array}{l}\text { Frequency of } \\
\text { Reporting }\end{array}$ & Daily & Monthly & Monthily & Monthly & Monthly & Daily & Monthly & Monthly & Monthly & Monthly & Quarterly \\
\hline $\begin{array}{l}\text { Source of } \\
\text { Update }\end{array}$ & Bloomberg. & $\begin{array}{l}\text { Bank of } \\
\text { Finland }\end{array}$ & $\begin{array}{l}\text { Bank of } \\
\text { Finland }\end{array}$ & $\begin{array}{l}\text { Bank of } \\
\text { Finland }\end{array}$ & $\begin{array}{l}\text { Bank of } \\
\text { Finland }\end{array}$ & Bloomberg & ETLA & $\begin{array}{l}\text { Bank of } \\
\text { Finland }\end{array}$ & $\begin{array}{l}\text { Bank of } \\
\text { Finland }\end{array}$ & ETLA & ETLA \\
\hline $\begin{array}{l}\text { Mode of } \\
\text { Reporting }\end{array}$ & On-line & On-line & On-line & On-line & On-line & On-line & On-line & On-line & On-line & On-line & On-line \\
\hline Confidentiality & Public & Public & Public & Public & Public & Public & Public & Public & Public & Public & Public \\
\hline $\begin{array}{l}\text { Frequency of } \\
\text { Publication }\end{array}$ & Daily & Monthly & Monthly & Monthly & Monthly & Daily & Monthly & Monthly & Monthly & Monthly & Quarterly \\
\hline
\end{tabular}




\section{Medium- ANd Long-Term Fiscal Strategies and Policy Trade-Offs}

This Appendix discusses the relative merits of two alternative strategies for addressing the demographic shock, described by the following scenarios and illustrated in Figure $1:^{i}$

- The first (baseline) scenario incorporates the government's medium-term spending plans, tax cuts equivalent to those indicated in Finland's Stability Program, and an increase in the effective retirement age by one year, as a rough assessment of the impact of recent pension reforms. ${ }^{2}$ Under such a strategy, fiscal surpluses would continue to swell over the medium term and gradually decline to a small deficit by 2030. The fiscal impact of population aging would be cushioned largely by the rise in the effective retirement age from 59 to 60 and the interest savings generated by the rapid eradication of the public debt. However, the unemployment rate - after falling over the medium-term in response to tax cuts and recent labor market reforms-would be trapped at $73 / 4$ percent, without additional actions. The employment rate, would drop back below 70 percent, in the absence of further shifts in retirement incentives, and GDP growth would decline quite rapidly already over the next ten years.

- The second (fiscal and pension reform) scenario assumes that the above policies are complemented by a more sizeable reduction in income taxes and social security contributions and decisive measures to curtail early retivement by an additional two years. In line with staff's recommendations, it is assumed that the tax burden on labor income is reduced by $2 \frac{1 / 4}{4}$ percentage points of GDP over $2001-03$ - some

$1 \frac{1}{4}$ percentage points of GDP more than in the baseline scenario-and $13 / 4$ percentage points of GDP over 2004-2010. As a result of smaller fiscal surpluses over the medium term, the public debt ratio would decline somewhat slower, but demographic pressures would be stemmed by the further increase in the effective retirement age to 62 years by 2010 . This, in combination with the more sizeable tax cuts, would set in motion a virtuous circle of higher employment creation, faster economic growth, and improved public finances over the long term, with a further noticeable decline in the unemployment rate. ${ }^{3}$ While not illustrated in Figure 1, additional benefits in all of the above areas could be achieved by further reforms to the labor market.

\footnotetext{
${ }^{1}$ Both are slightly modified versions of the scenarios described in detail in Finland: Selected Issues (SM/99/230).

${ }^{2}$ The scenario does not include the impact of the government's recent announcement to augment its original tax cut plans, as timing and magnitude are still uncertain.
}

${ }^{3}$ Figure 1 assumes that the elasticity of the employment rate with respect to reductions in the tax ratio is 0.4 -in the middle of a $0.3-0.5$ range, supported by cross-country empirical evidence, and consistent with earlier estimates for Finland (see SM/97/250 and SM/97/167). 
Figure 1. Finland: Long-Term Fiscal Scenarios, 1998-2030
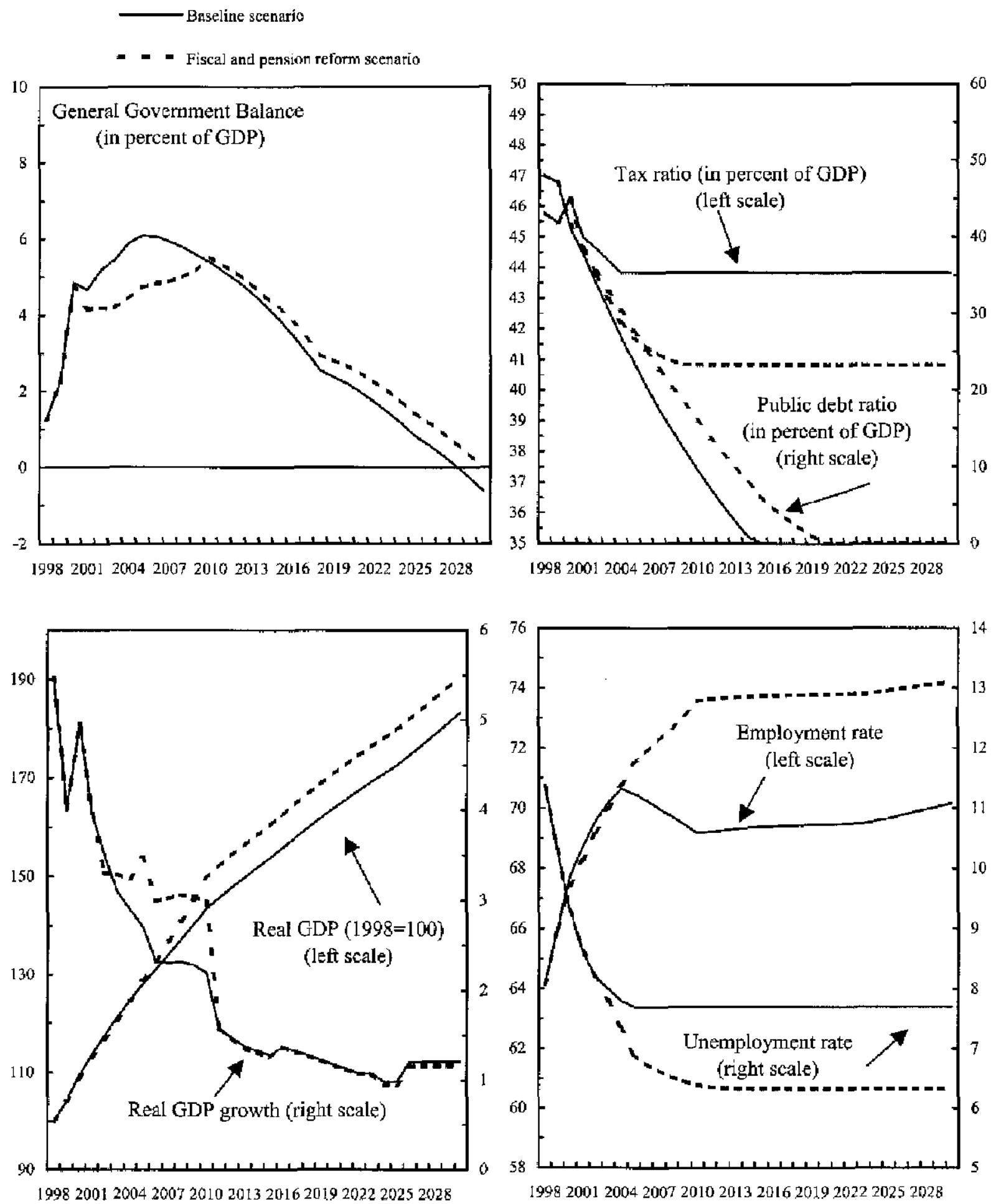

Source: IMF staff projections. 
Public Information Notice (PIN) No. 00/68

FOR IMMEDIATE RELEASE

August 31, 2000
International Monetary Fund $70019^{\text {th }}$ Street, NW

Washington, D. C. 20431 USA

\section{IMF Concludes Article IV Consultation with Finland}

On August 22, 2000, the Executive Board concluded the Article IV consultation with Finland. ${ }^{1}$

\section{Background}

Finland has completed its recovery from the severe recession of the early $1990 \mathrm{~s}$ with the help of sound macroeconomic policies, and economic growth is now increasingly sustained by the sectors of the "new economy". Real GDP increased at an average annual rate of $4 \frac{1}{2}$ percent over the past three years, while inflationary pressures have remained largely absent. Fiscal policies anchored on firm expenditure restraint have moved the public finances back into a sizeable surplus, and the viability of the banking sector has been restored. The expansion has been led by a very dynamic "high tech" sector, which, while still accounting for only 3 percent of employment, is generating nearly a third of the growth in real GDP.

The Finnish economy weathered the 1998-99 emerging market crisis with only a mild slowdown in economic growth, and the near-term outlook for economic activity is favorable. After a temporary slowdown in the first half of 1999, economic growth picked up toward the end of the year, driven by a sharp recovery in exports. This expansion in exports should continue in $2000-$ 2001 , as external competitiveness remains strong and the growth of domestic demand accelerates in the rest of the euro area. Domestic demand should also expand rapidly in Finland, with consumer and business confidence comforted by favorable employment and profit developments. Both the authorities and the staff project solid economic growth of the order of 5 percent in 2000 and 4 percent in 2001, with risks assessed to be larger on the upside. Consumer price inflation has picked up in the first half of 2000 to an average of around $23 / 4$ percent, with higher oil prices and housing costs accounting for some 1 and $1 / 2$ percentage

' Under Article IV of the IMF's Articles of Agreement, the IMF holds bilateral discussions with members, usually every year. A staff team visits the country, collects economic and financial information, and discusses with officials the country's economic developments and policies. On return to headquarters, the staff prepares a report, which forms the basis for discussion by the Executive Board. At the conclusion of the discussion, the Managing Director, as Chairman of the Board, summarizes the views of Executive Directors, and this summary is transmitted to the country's authorities. In this PIN, the main features of the Board's discussion are described. 
points, respectively. The latter have also contributed to a rise in core inflation (excluding energy and seasonal food) from a low rate of just above 1 percent in 1999 to slightly below 2 percent in May 2000 - some $3 / 4$ percentage points above the euro-area average.

The main challenges for economic policy are now predominantfy of a structural nature. In particular, (i) labor productivity is well below the euro-area average, and outside the high tech sector, productivity has increased at an annual rate of only 1.3 percent over the past three years; (ii) despite a significant fall in recent years, the unemployment rate at around 10 percent is high, even by European standards, and particularly excessive among the low-skilled; and (iii) the effective labor supply is limited by a low average retirement age of 59 years, which if not tackled, will significantly exacerbate the impending demographic shock, facing all of Europe: an insufficient number of workers to support a growing population of pensioners.

\section{Executive Board Assessment}

Executive Directors endorsed the thrust of the staff appraisal, acknowledging the important role of sound macroeconomic policies for Finland's impressive recovery from the depression of the early 1990 s. The economy was now engaged in a new phase of economic expansion, and rapid growth over the past years was set to continue in 2000-01, supported by a very dynamic high tech sector. The public finances were back in surplus; the viability of the banking sector had been restored; and so far, inflationary pressures had been subdued, notwithstanding accommodative monetary conditions, supported by a very competitive exchange rate.

Nonetheless, serious problems remained on the structural front that if not tackled promptly, could undermine the prospects for robust long-term growth and hinder Finland's adjustment to the impending demographic shock. Symptoms could be found in low productivity growth outside the high tech sector and a high rate of structural unemployment, which, combined with a low average retirement age, was limiting the effective labor supply. These problems were not unrelated to the heavy tax burden and to persistent rigidities in product and labor markets. Moreover, while overheating was not an imminent risk, price and wage pressures could emerge over the coming years. With a shrinking pool of cyclical unemployment to be absorbed, the growth potential of the economy could be sharply curtailed, unless labor market tensions and capacity constraints were alleviated by decisive measures to improve the flexibility and the supply response of the economy.

On the fiscal front, continued restraint on the growth of public expenditures was crucial, but needed to be complemented by a significant reduction in the heavy tax burden on labor income. The government's medium-term expenditure plans continued the process of fiscal consolidation, with sizeable surpluses cushioning the fiscal impact of growing demographic pressures, while providing scope for reductions in income taxes and social security contributions. With the favorable outlook in public finances, the government's intention of augmenting earlier announced tax cuts was welcome, and an overall reduction in the tax wedge of about $21 / 4$ percentage points of GDP appeared feasible over the 2001-03 period. This would be consistent with maintaining a sizeable structural surplus and imply an almost neutral fiscal stance at a time when monetary conditions in the euro area were likely to tighten. As to the composition of tax cuts, a mixed approach, combining targeted relief for low-income groups with across-the-board reductions in marginal rates, was regarded most effective in encouraging job 
creation at the low-skill level, while affecting performance incentives and residence decisions on a wider scale.

To avoid an emergence of inflationary pressures and adjust to the demographic challenges, the macroeconomic policy stance needed to be complemented by other measures on the structural front that would help expand the effective labor supply and enhance the supply response of the economy. In particular, the existing schemes for subsidized early retirement, which were established during the depression period of the early 1990 s, needed to be abolished to promote the reintegration of the age group of 55-65 years into the active labor force. Alsc, a closer link between pension benefits and life-contributions was seen as crucial to foster both work incentives and intergenerational faimess. In the labor market, social partners needed to allow for greater wage differentiation, commensurate with diverse productivity developments, in order to strengthen the demand for low-skilled labor. At the same time, the unemployment benefits system needed to be redesigned to enhance incentives for a quick reintegration into the active workforce. Finally, to dampen inflationary risks and foster economy-wide productivity growth, further reforms of product markets were crucial, including the removal of rigidities in land and housing markets, in order to promote labor mobility.

Public Information Notices (PINs) are issued, (i) at the request of a member country, following the conclusion of the Article IV consultation for countries seeking to make known the views of the IMF to the public. This action is intended to strengthen IMF surveillance over the economic policies of member countries by increasing the transparency of the IMF's assessment of these policies; and (ii) following policy discussions in the Executive Board at the decision of the Board. As part of a pilot project, the staff report for the 2000 Article IV consultation with Finland is also available. 
Finland: Selected Economic Indicators

\begin{tabular}{|c|c|c|c|c|}
\hline & 1997 & 1998 & 1999 & 200011 \\
\hline \multicolumn{5}{|l|}{ Real economy (change in percent) } \\
\hline GDP & 6.3 & 5.0 & 3.5 & 5.0 \\
\hline Domestic Demand & 6.0 & 5.4 & 1.9 & 3.6 \\
\hline Hamonized CP: & 1.2 & 1.3 & 1.3 & 2.7 \\
\hline Unemployment rate (in percent) $2 /$ & 12.7 & 11.4 & 10.2 & 9.3 \\
\hline Gross national saving (in percent of GDP) & 24.1 & 24.7 & 25.2 & 26.5 \\
\hline Gross domestic investment (in percent of GDP) & 18.5 & 19.0 & 19.9 & 20.8 \\
\hline \multicolumn{5}{|l|}{ Publlc finances (general government, in percent of GDP) } \\
\hline Overall balance & -1.5 & 1.3 & 2.3 & 4.8 \\
\hline Primary balance & 0.4 & 3.0 & 3.7 & 6.1 \\
\hline Gross debt (EMU-definition) & 53.7 & 48.3 & 47.1 & 41.6 \\
\hline \multicolumn{5}{|l|}{ Money and credit (end of period, percentage change) $3 /$} \\
\hline M3 4r & 7.2 & 2.5 & 6.0 & 7.3 \\
\hline Total domestic credit & 1.0 & 11.9 & 10.6 & 7.2 \\
\hline \multicolumn{5}{|l|}{ Interest rates (year average) 5 ) } \\
\hline Three-month money market & 3.2 & 3.6 & 3.0 & 3.9 \\
\hline Ten-year government bonds & 6.0 & 4.8 & 4.7 & 5.6 \\
\hline \multicolumn{5}{|l|}{ Balance of payments (in percent of GDP) } \\
\hline Trade balance & 9.5 & 9.7 & 9.1 & 9.5 \\
\hline Current acoount & 5.6 & 5.7 & 5.3 & 5.7 \\
\hline \multicolumn{5}{|l|}{ Fund position (as of end-June 2000) } \\
\hline Fund holding of currency (in percent of quota) & \multicolumn{4}{|c|}{69.0} \\
\hline Holdings of SDRs (in percent of allocation) & \multicolumn{4}{|c|}{122.2} \\
\hline Quota (in millions of SDRs) & \multicolumn{4}{|c|}{$1,263.8$} \\
\hline \multicolumn{5}{|l|}{ Exchange rate } \\
\hline Exchange rate regime & \multicolumn{4}{|c|}{ EMU Member } \\
\hline Present rate (July 24,2000$) 6 /$ & \multicolumn{4}{|c|}{ US\$ 0.934 per вuro } \\
\hline Nominal effective exchange rate (increase in percent $7 /$ & -2.5 & 0.0 & -2.7 & -5.8 \\
\hline Real effective exchange rate (increase in percent) 8 r & -4.9 & -0.1 & -2.9 & -5.4 \\
\hline \multicolumn{5}{|c|}{$\begin{array}{l}\text { Sources: Data provided by the Finnish authorities, Imternational Financial Statistics; and IMF staff } \\
\text { estimates. } \\
\text { 1/ IMF staff projections. } \\
\text { 2/ Consistent with Eurostat methodology. } \\
\text { 3/ For } 2000,12 \text {-month increase to May. } \\
\text { 4/ From } 1999 \text { onward, Finnish contribution to euro area M3. } \\
\text { 5/ For } 2000 \text {, average through June. } \\
6 / \text { The conversian rate of the Finnish markka is } 5.94573 \text { per euro. } \\
\text { 7/ For } 2000 \text {, average } 12-\text { month increase through April. } \\
8 / \text { Based on relative normalized unit labor cost. For } 2000 \text {, average 12-month increase through Ju }\end{array}$} \\
\hline
\end{tabular}

